\title{
The Little Words That Matter: Discourse Markers in Teacher Talk
}

\author{
Yeni Karlina, Suparno, Endang Setyaningsih \\ English Education Department \\ Sebelas Maret University of Surakarta
}

Email: yenikarlina93@gmail.com

\begin{abstract}
The aim of this paper is to discuss one specific aspect of classroom interaction and language use in language classroom, namely discourse markers (DMs). This research uses case study method. Using data obtained from two English teachers teaching six EFL classrooms in a high school in Surakarta, this study describes the occurrence and textual functions of DMs used by the teachers. The data analysis reveals that there are 19 types of DMs, either in English, Indonesian, or Javanese language, used by both teachers in their classroom talk. This paper also provides an account of a number of textual functions fulfilled by those DMs which may contribute greatly to the coherent and smooth flow of the discourse organization generated in classroom interaction. The fact that DMs are valuable resources to facilitate the structuring of classroom discourse suggests that there should be an increasing awareness of English teachers about the use of DMs in teacher talk.
\end{abstract}

Key words: Discourse markers, teacher talk, classroom interaction

\section{Abstrak}

Tujuan dari artikel ini adalah untuk membahas suatu aspek khusus dari interaksi kelas dan penggunaan bahasa di kelas bahasa yakni penanda wacana (DMs). Penelitian ini menggunakan metode studi kasus. Menggunakan data yang diperoleh dari dua guru mata pelajaran Bahasa Inggris yang mengajar di enam kelas Bahasa Inggris sebagai bahasa asing di salah satu SMA di Surakarta, penelitian ini mendeskripsikan kejadian dan fungsi tekstual dari DMs yang digunakan oleh guru. Analisis data menunjukkan bahwa terdapat 19 DMs baik dalam Bahasa Inggris, Bahasa Indonesia, atau Bahasa Jawa yang digunakan kedua guru dalam ujaran guru di kelas. Artikel ini juga menguraikan sejumlah fungsi tekstual DMs yang secara signifikan berkontribusi terhadap alur organisasi diskursus kelas yang koheren dan lancar dalam interaksi kelas. Fakta bahwa DMs adalah perangkat berharga untuk memudahkan struktur diskursus kelas meyarankan bahwa harus ada peningkatan kesadaran tentang penggunaan DMs dalam ujaran guru.

Kata kunci: Penanda wacana, ujaran guru, interaksi kelas

Given the essential role entailed by the language of instruction in ESL/ EFL

classrooms, investigating the language use of teachers in language classroom has 
become an intriguing research focus for decades. The existing researches on teacher talk mainly emphasize issues related to teacher's questioning behavior (Long and Sato, 1983; Shomoossi, 2004), language functions of teacher talk (Hughes, 1981), teacher talk and language acquisition (Tang, 2009; Setiawati, 2012), and the structure of teacher talk (Walsh, 2011).

While a considerable number of studies adequately focus on those general elements, small details in teacher talk remain largely unexplored. As studies on classroom language seek to portray what actually happens in the classroom, even a minor element making up the whole talk should not be neglected. One of the small elements of teacher talk which affect the flow of the talk is discourse markers (DM henceforth).

Investigating DMs in teacher talk is particularly beneficial since teacher talk is an indispensable element of language classroom interaction which primarily serves two functions, i.e. as the language input / a model of target language use and as a tool for managing classroom processes (Sesek, 2005, p. 225). In regard to those very functions, it is important that language teachers fine-tune their language use to facilitate them meeting the instructional objectives. Teacher talk needs to be organised accordingly so that the coherence and cohesion of the talk can be maintained. When texts are not coherent, they do not make sense or they make it difficult for the reader/listener to understand (Halliday and Hassan, 1976, p. 324). In order to make the speech coherent, consistent, easy to follow and understandable, a speaker can use cohesive signposts in discourse, that is, DMs (Granger, 1996, p.80 in Muller, 2005, p. 19). In short, DMs' contribution towards a well-organised 
speech in many ways benefits the flow of the discourse. This makes DM an inevitable element in classroom teacher talk.

Although there has been a consensus on the significance of DMs in oral communication, items that constitute DMs are still open for a debate. As a matter of fact, in this study DMs categorisation is based on a set of criteria synthesised from experts' views (Fraser, 1999; Schourup, 1999; Muller, 2005; Fung, 2011). Those characteristics are: (1) Connectivity; (2) Optionality; (3) Non-truth conditionality; (4) Multi-categoriality; (5) Initiality; and (6) Multi-functionality.

Brinton (1996) in Castro (2009, p. 60) claims that DMs serve a variety of functions which she groups into two main categories. First, the textual function which is related to the way the speaker structures meaning as text, creating cohesive passages of discourse, and using language in a way that is relevant to the context. And second, the interpersonal function refers to the nature of the social exchange, that is, the role of the speaker and the role assigned to the hearer. Considering the importance of how teachers need to fine-tune their classroom talk to accomplish the intended functions and be the role model of target language use, this study makes the former function the focus of the investigation.

Research on DMs has abounded since the 1980s when Schiffrin (1987) proposed her seminal work on DMs. Ever since that break through, more and more studies include analyses and descriptions of the use of DMs in different languages, genres and contexts. Anyhow, studies on the use of DMs by language teachers remain limited in number.

Castro (2009) who studied the occurrence of DMs in EFL classrooms in Columbia used by both teachers and students shows that the teachers exhibit 
relatively higher use of DMs compared to the students with the percentage of $61 \%$ to $39 \%$. A study conducted by Fung (2011) explores the attitudes of Hong Kong English teachers towards the pedagogic values of DMs using both the quantitative and qualitative approach indicate a very positive perception of the pragmatic and pedagogic values of DMs by the subjects. Khazaee (2012) who conducted a research on the use of DMs by Iranian English teachers in EFL classrooms pointed out that two of the three teachers acknowledge the importance of DMs in spoken discourse while the other one believes that DMs occur automatically with no function.

There has not been research on this matter in Indonesian context of language classroom. Therefore this study attempts to fill this gap and provide an exploratory account of DMs use by teachers in English classrooms in Indonesian setting.

\section{RESEARCH METHODS}

This research was conducted using qualitative case study method. The research was conducted from April to June 2014 in both the regular and acceleration program of SMA Negeri 3 Surakarta. The sources of the data were events, informants, and documents. The data were collected through observation, interviews, and document analysis.

The teachings of T1 in three English classrooms in the acceleration program and T2 in three English classrooms in the regular program, 2 periods for each class, were recorded. One period equals 45 minutes of teaching. The recorded classroom interactions were transcribed. They were transcribed using specific transcription conventions which were very useful in providing the maximum transmission of 
contextual information and to ensure accuracy. Occasional speech errors made by participants were not corrected; instead, they were transcribed as they had actually occurred. The transcribed utterances of the teacher talk were the primary data of this research. The data were combined with the result of the classroom observation, lesson plan analysis, textbook analysis and verified with the result of the interviews with teachers and students. The data were analyzed using interactive model of qualitative data analysis technique including data reduction, data display, and drawing conclusion/ verification (Miles and Huberman, 1992, p. 20).

\section{FINDINGS AND DISCUSSIONS}

The transcribed talk of both teachers in the classroom suggests that there are 19 kinds of DMs in English, Indonesian, and Javanese language used by T1 and T2 in their talk. Those DMs are summarized in table 1.

Table 1. The classification of DMs used by teachers in English classroom

\begin{tabular}{l|l|l|}
\hline \multicolumn{2}{c|}{ English DMs } & \multicolumn{2}{|c}{ Indonesian DMs } & Javanese DMs \\
\hline a) Okay & n) Oke & s) Sik-sik \\
b) So & o) Jadi & \\
c) Er and em & p) Nah & \\
d) Well & q) Bentar bentar & \\
e) Now & r) Tapi & \\
f) And & & \\
g) But & & \\
h) Because & & \\
i) And then & & \\
j) Next & & \\
k) If & & \\
1) By the way & & \\
m) I mean & &
\end{tabular}

Although both teachers use more than one languages of instruction in their classroom talk, English language is the major language through which teaching materials are explained and classroom activity procedures are completed. The use of 
other languages which are Indonesian and Javanese language is complementary to the use of English as they are used in particular contexts which require the code switching, for instance the use of Indonesian language when additional explanation for certain concept is needed and the use of Javanese language for the purpose of icebreaking. It is therefore reasonable that the table above shows that DMs in English (TL) outnumber DMs in either Indonesian (L2) or Javanese (L1) language.

The DMs mentioned above serve textual functions in a range of contexts. Textual functions of DMs are how DMs serve as devices that aid the speaker to structure and organize the discourse to create discourse coherence. This coherence can be classified into two kinds, i.e. global coherence and local coherence. Establishing global coherence has something to do with employing DMs use to mark important change or phase of the whole discourse. On the other hand, enforcing local coherence of the discourse can be done by making use of DMs to point out the interdependence of smaller discourse units or the so-called 'adjacent unit of discourse' (Fung, 2011, p. 233). Therefore, DM should be analyzed in its context of use that is both the local context and the sequence of talk in which they occurred during classroom interaction.

Below is the sample of DMs function analyzed in the context in which they occur. The excerpt below shows the use of DM 'okay' by the teacher. This extract was taken from an observation at class XI Acceleration 1.

\section{Extract 6}

T1 was asking Ss if they were doing well. Some said that they were not.

$\mathrm{T} \quad$ : How are things going with you? Fine?

Ss : Bad

T : Bad? Who says 'bad'?

Ss : Yn 
T : Why is it bad, Yn? You got something?

Yn : Because it's not good.

Ss : (laughter)

T : Okay, guys, you still remember I've asked you to update your Edmodo?

Ss : Nooo

(Classroom interaction transcript 1; Thursday, 24 April 2014)

Extract 6 shows that T1 used the DM 'okay' to change the topic. At the beginning T1 and Yn were talking about how Yn was not feeling well. The reason for that answer was quite funny so students were laughing at that. Feeling that the talk on that matter was enough, $\mathrm{T} 1$ then switched the topic into the assignment given to the students before. To mark this switch, she used DM 'okay'.

Based on the transcription of the classroom interaction observed by the researcher and the transcripts of interview with both teachers and students, the researcher comes to a formulation of the textual functions performed by DMs in classroom setting as follows.

Table 2. The textual functions of DMs used by the teachers

\begin{tabular}{lll}
\hline No. & \multicolumn{1}{c}{ Textual Function } & \multicolumn{1}{c}{ DMs } \\
\hline 1. & to mark the opening of the discourse & okay, so, oke \\
2. & to signal topic switch & okay, oke, well, by the way, now, nah \\
3. & to mark the closing of the discourse & Okay \\
4. & to keep the speaking turn & er, em, bentar-bentar, sik-sik \\
$\mathbf{5 .}$ & to relinquish the speaking turn & okay, so \\
$\mathbf{6 .}$ & to indicate result or conclusion & so, jadi, nah \\
7. & to signal contrastive relation & but, tapi \\
$\mathbf{8 .}$ & to mark sequential relations & next, and then \\
$\mathbf{9 .}$ & to signal the continuation \&addition & And \\
$\mathbf{1 0}$ & to indicate repairs of the speech & I mean \\
$\mathbf{1 1}$ & to show condition relation & If \\
$\mathbf{1 2}$ & to show causal relation & Because \\
\hline
\end{tabular}

DMs are used in a various way by both teachers to suit the context in which the DMs are used. Therefore, it is common to find that the frequency of DMs 
occurrence in classrooms is different from each other. In general, the comparison of DM used by teachers among classrooms can be observed in table 3 .

Table 3. The occurrence of DMs use in every classroom

\begin{tabular}{|c|c|c|c|c|c|}
\hline Class & Teacher & Material & $\begin{array}{l}\text { Observation } \\
\text { time } \\
\text { allocation }\end{array}$ & $\begin{array}{c}\text { Language(s) } \\
\text { used }\end{array}$ & $\begin{array}{l}\text { Top five DMs } \\
\text { used (in an } \\
\text { order) }\end{array}$ \\
\hline XI Acc. 1 & $\mathrm{~T} 1$ & $\begin{array}{l}\text { Pluralisation } \\
\text { (Report text) }\end{array}$ & $2 \times 45$ & $\begin{array}{l}\text { English: } \\
\text { Indonesian: } \\
\text { Javanese }\end{array}$ & $\begin{array}{l}\text { Okay (72), er } \\
(32) \text {, so }(27) \text {, } \\
\text { but (20), and } \\
\text { then (19) }\end{array}$ \\
\hline XI Acc. 2 & $\mathrm{~T} 1$ & Causative & $1 \times 45^{\prime}$ & $\begin{array}{l}\text { English: } \\
\text { Indonesian: } \\
\text { Javanese }\end{array}$ & $\begin{array}{l}\text { Okay (41), so } \\
(29) \text {, er }(21), \\
\text { and then }(18) \text {, } \\
\text { because (14) }\end{array}$ \\
\hline XI Acc. 2 & $\mathrm{~T} 1$ & Giving advice & $2 \times 45^{\prime}$ & $\begin{array}{l}\text { English: } \\
\text { Indonesian: } \\
\text { Javanese }\end{array}$ & $\begin{array}{l}\text { Okay (68), so } \\
(32) \text {, and then } \\
(28) \text {, er }(26) \text {, } \\
\text { and }(20)\end{array}$ \\
\hline XI IPA 1 & $\mathrm{~T} 2$ & $\begin{array}{l}\text { Subjunctive in } \\
\text { Conditional } \\
\text { Sentence }\end{array}$ & $2 \times 45^{\prime}$ & $\begin{array}{l}\text { English: } \\
\text { Indonesian }\end{array}$ & $\begin{array}{l}\text { Okay (35), } \\
\text { oke (16), er } \\
(14), \text { and } \\
(10), \text { next (8) }\end{array}$ \\
\hline XI IPA 2 & $\mathrm{~T} 2$ & $\begin{array}{l}\text { Subjunctive 'as } \\
\text { if' }\end{array}$ & $2 \times 45^{\prime}$ & $\begin{array}{l}\text { English: } \\
\text { Indonesian }\end{array}$ & $\begin{array}{l}\text { Okay (43), er } \\
(21) \text {, so }(15) \text {, } \\
\text { and (9), but } \\
(7) \text {. }\end{array}$ \\
\hline XI IPS 4 & $\mathrm{~T} 2$ & $\begin{array}{l}\text { Subjunctive in } \\
\text { Conditional } \\
\text { Sentence }\end{array}$ & $2 \times 45^{\prime}$ & $\begin{array}{l}\text { English: } \\
\text { Indonesian }\end{array}$ & 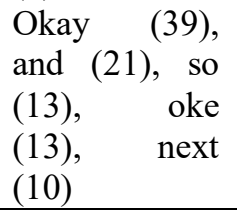 \\
\hline
\end{tabular}

It is interesting to see that the top-five DMs used by both teachers are ranging at more or less similar choices of DMs. DM 'okay' is the most frequent DMs used by both teacher due to its high multi-functionality. As DM 'okay' can aid the teacher in opening and closing the discourse, signal topic switch and progression of classroom procedure, and assist the turn-management behavior, its frequent use in teacher talk in all classrooms seems to be a reasonable phenomenon. In all classrooms this DM outnumbered any other DMs with a significant difference in frequency. Besides 
'okay', DM 'so' is also used by both teachers in a relatively high frequency. As this DM can perform various functions such as a result or conclusion marker, opening frame marker, and turn-allocation marker, the use of this DM in teacher talk is preferable by both teachers.

The next three DMs used in every classroom are different each other. In XI Acceleration 1 where T1 delivered materials about 'Pluralisation' in a lecture teaching method, filler 'er' appeared to be DMs used by T1 repeatedly. The nature of students of XI Acceleration 1 who are very talkative and active requires $\mathrm{T} 1$ to employ a strategy to manage the turn-management wisely. The absence of turnkeeper marker would possibly distract the delivery of the materials as students tend to actively interrupt the teacher's explanation. The frequent use of DM 'and then' and 'but' could be related to how those markers facilitated teacher's explanation about pluralisation which dominated the whole classroom talk in general.

In XI Acceleration 2, sequencing marker 'and then' hold a significant role in the structuring of the teacher's explanation which happened to be the centre of the classroom activity. It is therefore reasonable to that $\mathrm{T} 1$ also used addition marker 'and' for the purpose of elaboration of explanation. Besides, the teacher's explanation which dominated the classroom activity makes the teacher used filler 'er' in a high frequency for the purpose of avoiding dead-air silence during explanation and the turn-keeper which enables the teacher to hold the floor.

In XI Acceleration 2 where T1 taught speaking skill of giving advice through games, the relatively high use of DM 'and then' is due to the functions of DM to mark sequential relations. The game consisted of sequences where a pair of students presented their work followed by another pairs. Thus T1 used frequent 'next' to deal 
with the orders of presentation. The use of games where students got more turns to speak results in a dynamic turn-management behavior. This turn-allocation situation requires a strategy $\mathrm{T} 1$ should use in her talk for instance incorporating DMs 'er' functioning as turn-keeper.

A relatively high use of Indonesian language in class XI IPA 1 led into how T2 frequently used Indonesian DM 'oke' in his talk. This use could not be observed in teacher's explanation about the materials as in explaining the materials $\mathrm{T} 2$ used more English than Indonesian language. Not to mention, this DM appeared more often in T2's dialogic talk with his students.

In class XI IPA 2 in which the main activity was students doing an exercise after a brief explanation about the material of Subjunctive 'as if' and 'would rather' T2 used DMs to point out the relevance relation between utterances. It was done through some occurrence of DMs 'and' and 'but' in his speech.

In class XI IPS 4 in which the use of 'oke' in marking transition in the explanation and classroom procedures seemed to be something reasonable for a class in which the main activities were teacher's explanation about the materials followed by some exercise and test. The frequent use of 'next' was due to T2's attempt to point out the sequential relation between numbers of questions he dictated for the exercise and the test.

As DMs are context-dependant items serving more than one function simultaneously, it is not surprising that DMs most frequently used by both teachers in their classroom talk are DM with high multi-functionality such as 'okay', 'so', 'er', 'and' and 'and then'. 
Based on the previous discussion, there is a common finding that the major function performed by most DMs in teacher talk is to mark topic switch, including transition of classroom procedures. Teachers uniformly use DM to aid them avoid abrupt topic switch and classroom procedure progression. This function in academic discourse is particularly common because the procedures of classroom discourse are usually planned by the teachers. Referring to the lesson plans they have planned previously, teachers usually prepare the substantive content of what they are about to say in the classroom. So, they come up to the classroom bringing the outline of what they want to say in the classroom arranged in their head. This outline usually consists of several subtopics delivered in different phases of the lesson stated in their lesson plan. It is reasonable that they use DMs to facilitate them mark the transitions of topics, subtopics, and the progression of the lesson phases, including the opening and closing of classroom discourse.

In addition, it has been widely acknowledged that classroom possesses special turn-management behavior which is in many ways different from turn allocation in natural communication setting. The function of DMs to assist teachers in turn-management behavior is highly dependent on the characteristics the students and the classroom activities. In all the six classrooms it can be seen that both $\mathrm{T} 1$ and T2 employ the use of DMs to perform the function of keeping turn because teachers usually favor uninterrupted speaking turn in their explanation. In classroom where the students tend to be active and talkative and in classrooms in which the activities are student-centered, teacher's ability to manage the speaking turn is important to ensure the success of the teaching and learning activity. In giving the speaking turn to the students, it turns out that T1 marked her turn giving with some DMs while T2 
whose class did not show any noticeable turn-giving behavior did not use any DM to release the speaking turn or his turn-giving behavior was unmarked by DMs.

The local textual functions of DM in showing the cohesive relations can be observed in most classes as this function is admitted essential in helping the teacher in creating a coherence piece of discourse. It is mainly because teachers believe that they are the role model of the use of TL exemplified by the students. A wellmannered use of English which starts from simple thing like incorporating the use of DMs in the speech becomes a thing teachers need to encompass in front of their students.

Above-elaborated discussion suggests that there is no one-on-one mapping between DMs and what textual function they are serving. This is why there must be several affecting considerations made by teachers upon the decisions why and how certain DM is chosen compared to another DM. Among the affecting factors are personal differences between $\mathrm{T} 1$ and $\mathrm{T} 2$ in terms of gender and exposure towards DMs use, the difference in teaching and learning activities including the teaching materials, the distinctive characteristics of the class, and the kinds of language used as the language of instruction. A more in-depth research regarding this stylistic difference of DMs use between speakers, in this case the speakers are teachers, will be very much enlightening.

\section{CONCLUSIONS AND SUGGESTIONS}


The research finding and discussion lead into a conclusion that both teachers expose relatively frequent use of DMs in their classroom talk to organize the classroom discourse. The DMs used by the teachers in the classrooms cover DMs in English language such as okay, so, filler er and em, well, now, and, but, because, and then, next, if, by the way, and I mean, DMs in Indonesian language such as oke, jadi, nah, bentar bentar, and tapi and DM in Javanese language i.e. sik sik, as occasionally used by $\mathrm{T} 1$ in her talk. In general the use of English DMs outnumbers Indonesian and Javanese DMs as the major language in the classroom interaction is English. Among those DMs, DM okay, so, and then, and and er are the most preferable DMs both teachers use in the teacher talk due to the high multi-functionality of those DMs in helping teachers in the structuring and organizing the classroom discourse.

The next point that can be inferred from the research findings and discussions is that the above-explained DMs fulfill textual functions that help the teachers create the coherence of the classroom discourse. As there is no exact one-on-one mapping between the DM and what functions are performed by that particular DM, the functions of the DMs used by the teachers must be traced from the context in which they occur. It is therefore reasonable that Schiffrin asserts that DMs are contextdependant so that they "can gain their function through discourse" (2001, p. 60).

The textual functions performed by DMs used by teachers in each classroom vary. Anyhow, there is a uniformity that the major function performed by most DMs in teacher talk is to mark topic switch, including transition of classroom procedures. Teachers often use DMs to facilitate them mark the transitions of topics, subtopics, and the progression of the lesson phases, including the opening and closing of classroom discourse. In addition, both $\mathrm{T} 1$ and $\mathrm{T} 2$ employ high use of DMs to 
perform the function of keeping and relinquishing the speaking turn. Those textual functions are particularly common in academic discourse. Therefore DMs which serve those functions tend to outnumber other DMs. The absence of DMs in teacher talk will result in a scattered piece of talk with abrupt jumps here and there. Furthermore, the use of DMs in teacher talk is believed to make the teacher talk sound smooth, natural, and spontaneous. It is therefore justifiable to claim that DMs are the little words that matter.

Theoretically, the fact that the use of DMs is viewed beneficial implies that there should be an increased awareness on the textual functions of DMs to facilitate the structuring and organization of the teacher talk. A sound awareness and understanding on the DMs use and the roles they play in spoken discourse can lead to an effective use of DMs in teacher talk.

Practically, the implication leads to how the incorporation of DMs use into teacher training courses becomes necessary in order to enhance fluent and naturalistic conversational skills of DMs use so that in the end of the day teachers can use the DMs effectively. In achieving this, access to corpus data, regional variations, and recordings from everyday conversation are potentially effective ways, particularly in Indonesia where exposure to authentic formal and informal English conversations is on the whole limited.

\section{REFERENCES}


Castro, Claudia Marcela Chapetón. (2009). The use and functions of discourse markers in EFL classroom interaction. Profile Issues in Teachers' Professional Development. 11, pp. 57-77. Retrieved from http://www.redalyc.org/articulo.oa?id=169214144005

Fraser, B. (1999). What are discourse markers? Journal of Pragmatics 31(7), 931952.

Fung, Loretta. (2011). Discourse markers in the ESL classroom: A survey of teachers' attitudes. The Asian EFL Journal Quarterly 13 (2), 199-248

Halliday, M. A. K. and Hasan, Ruqaiya. (1976). Cohesion in English. London: Longman.

Hughes, Glyn S. (1981). A handbook of classroom English. Oxford: Oxford University Press

Khazaee, Hossein. (2012). Use of discourse markers by Iranian teachers of English as a foreign language. Journal of Basic and Applied Scientific Research 2(9), 8912-8917

Long, M. H., \& Sato, C. J. (1983). Classroom foreigner talk discourse: forms and functions of teachers' questions. In Seliger, H. W., \& Long, M. H. (eds.), Classroom-oriented research on second language acquisition (pp. 268-85). Rowley, Mass.: Newbury House.

Miles, M. B., and Hubberman, A. M. (1994). Qualitative data analysis: A sourcebook of new methods. California: Sage

Müller, Simone. (2005). Discourse markers in native and non-native English discourse. Amsterdam: John Benjamins Publishing Co.

Schourup, Lawrence (1999). Tutorial overview: Discourse markers. Lingua 107, $227-265$.

Schiffrin, D. (1987). Discourse markers. Cambridge: Cambridge University Press.

Sesek, Urska. (2005). “Teacher English: teacher's target language use as cornerstone of successful language teaching." in Smiljana Komar and Uros Mozetic (eds), English Language and Literature Studies in the Context of European Language Diversity, 2, 1-2.

Setiawati, Liani. (2012). A descriptive study on the teacher talk at EYL classroom. Indonesian Journal of Applied Linguistics 1 (2), 33-48 
Shomoossi, Nematullah. (2004). The effect of teachers' questioning behavior on EFL classroom interaction: a classroom research study. The Reading Matrix, $4(2), 96-104$

Tang, Eunice. (2011). Non-native teacher talk as lexical input in the foreign language classroom. Journal of Language Teaching and Research 2(1), 45-54

Walsh, Steve. (2011). Exploring classroom discourse: language in action. London: Routledge. 